\title{
Modernity and the Idea of Progress
}

\author{
Angelos Mouzakitis* \\ Sociology, University of Crete, Rethymnon, Crete, Greece
}

This paper aims to show the centrality the concept of progress occupies explicitly and implicitly in social theory, in relation to the theorization and understanding of modernity; it also raises the question whether in times where Eurocentrism, logocentrism, and indeed almost every claim of supremacy are rightly viewed with suspicion, it is possible to think of modernity without relying on some interpretation of the notion of progress. Arguably, the theme of progress, together with the complementary notion of decline, can be considered as a key-component of discourses concerning modernity and has played a major role in the shaping of social theory. Comte and Durkheim relied in different ways in the idea of progress and the same holds for Marxist accounts of social change. Even later, sociological theories address modernity from the perspective of progress, Parsons being exemplary in this respect. Moreover, theoretical discourses adopting a critical or even hostile attitude against the modern project often question the idea of progress and are woven around the representation of modernity in terms of decline and regression into unreason, as, e.g., Adorno and Horkheimer's Dialectic of Enightment. Arguably, the

OPEN ACCESS

Edited by:

Maurizio Meloni,

University of Sheffield, UK

Reviewed by: Kanakis Leledakis,

Panteion University, Greece John Cromby, University of Leicester, UK

${ }^{*}$ Correspondence: Angelos Mouzakitis amouzakid@uoc.gr

Specialty section: This article was submitted to Sociological Theory, a section of the journal

Frontiers in Sociology

Received: 06 September 2016 Accepted: 28 February 2017

Published: 20 March 2017

Citation:

Mouzakitis A (2017) Modernity and the Idea of Progress.

Front. Sociol. 2:3. doi: 10.3389/fsoc.2017.00003 imagery of progress informs the distinction between society and community, which is also hidden behind Habermas's more recent theorization of societies in terms of systems and lifeworlds. Finally, the question regarding the possibility of partially disentangling the theorization of modernity from the idea of progress is pursued via a critical assessment of Eisenstadt's multiple modernities and Wagner's theorization of modernity in terms of responses given to basic problématiques.

Keywords: modernity, progress/decline, social change, critique of reason, community/society, system/lifeworld

\section{INTRODUCTION}

Peter Wagner expresses a widely shared view when he writes that modernity "has always been associated with progress" (Wagner, 2012, p. 28), since belief in endless progress is often identified as one of the main characteristics of the Enlightenment (see Wagner, 2016). Arguably, the word "association" must have been carefully employed by this author in this context with the aim to avoid any strong claims concerning the possible identity between modernity and conceptions of progress, while pointing at the same time to a certain non-accidental congruence between the two "terms."

However, there is little doubt that the idea of "an immanent and indefinite progress" that gradually replaced the medieval belief in providence is inextricable woven with modernity, as it emerged in the midst of the querelle des anciens et des modernes in philosophy and the arts and subsequently spread out to embrace various aspects of European societies. Löwith claims that this new belief in progress, which almost became "a religion," would be impossible without the questioning of the dogma of divine providence but ironically in gradually replacing it also had to assume its function, viz. it had to "foresee and to provide for the future" (Löwith, 1949, p. 60). Therefore, the idea of progress 
that-together with the concept of revolution-shaped the horizon of historical expectations in the early stages of modernity and gave birth to the genre of the philosophy of history, exemplified in its very origins an ambivalence toward the medieval conception of the world, being "Christian by derivation" and "anti-Christian by implication" as Löwith (1949) observes (p. 61). It is equally apparent that currently, grand narratives of progress seem rather unpopular and redundant, but this hardly means that all notions of progress are irrelevant to late modern societies or to our attempts to understand present forms of modernity, as Peter Wagner rightly observes in the forward to his last contribution to the problem of progress (Wagner, 2016).

Arguably, conceptions of progress can be traced in different aspects of discourses about modernity, ranging from everyday conceptions and stereotypes about the "modern condition" to slightly paraphrase Lyotard-and sociological or philosophical accounts of modernity. It is however only with the latter that I am going to deal in this short excursion on progress. In what follows I do not attempt to provide an exhaustive account of the various phases the idea of progress underwent between the eighteenth century and the present, as this would require a separate study ${ }^{1}$ (Nisbet, 1994). Instead, I focus on the transference of the notion of progress from the field of the philosophy of history to that of social theory and the impact of progress to the wider theorizing of social change. I then move on to consider the ways in which the entanglement of the imagery of progress with modernity has shaped core dichotomies in social theory, such as those between community/society and systems/lifeworlds. Finally, I turn my gaze to the ways in which the belief in progress that underlined modernization theories has been challenged by Eisenstadt's multiple modernities approach and to the prospects opened up by Wagner's more recent attempts to theorize the relationship between progress and current modern projects.

\section{THE PHILOSOPHY OF HISTORY}

On the level of theoretical discourses that explicitly or implicitly tackle the problems of modernity, an often unacknowledged commitment to some notion of progress is traceable at first sight in various accounts of social change. This is hardly surprising, given the elective affinities between the "scientific" endeavor characteristic of early sociology to discover the mechanisms underlying socio-historical change and the field of the philosophy of history, where an explicit link between progress and historical change first emerged, partly as a result of the development of the concept of "world history" as well as the conception of "humanity" as the at-once singular/collective subject of history. ${ }^{2}$ One can always

\footnotetext{
${ }^{1}$ An extended-and scholarly-presentation of this sort can be found in the second part of Nisbet's History of the Idea of Progress, and especially in chapters six and seven (Nisbet, 1994).

${ }^{2}$ Indeed, the critique of the very conception of universal history entails that the concept of humanity also became the object of critique. However, despite the fragmentation of human beings, groups, civilizations, and whole socio-historical formations, I believe the concept is still indispensable at least as a regulative principle, as Ricoeur proposed in his exchange with Castoriadis in 1985, or as an imaginary signification as Castoriadis proposed in the same context (Castoriadis and Ricoeur, 2016, p. 66-68).
}

distinguish of course between "weaker" conceptions of progress as in Kant's Idea of a Universal History and more radical ones as in Hegel's Phenomenology and Lectures on the Philosophy of History as well as in Marx and Engels and in some versions of Marxism. Indeed, a good number of Marx's own writings seem to support the idea that Marx was himself to an extent under the spell of the widespread belief in progress. Although it is impossible to do justice here to the variety and richness of the responses from friends and foes to Marx's works in relation to the problem of progress, it would be unwise to completely refrain from highlighting some aspects of it.

It looks like until the Second World War, quite a few Marxists felt comfortable with the notion of progress. Thus, in his attempt to define "orthodox" Marxism in his classic work History and Class Consciousness, Lucaks still saw no fault in claiming that "by adopting the progressive part of the Hegelian Method" Marx was able to reveal "the real substratum of historical evolution" (Lucaks, 1972, p. 17-emphasis added). Some decades later, Hannah Arendt arguing from a completely different intellectual perspective critically observes that in Marx's "dream of a classless society...does a last, though utopian, trace of the eighteenth century concept [of progress] appear" (Arendt, 1973, p. 143).

However, even from the early twentieth century, Marxists of sorts have also attempted to trace in Marx's works non-determinist elements and in general have questioned the very notion of necessary historical development. Balibar (1995) presents us with a fine example of this attitude as he argues that Marx's works are Janus-faced. According to Balibar in texts like The Communist Manifesto, The German Ideology, the "introduction" of 1859 to The Critique of Political Economy and the first volume of The Capital Marx appears as a thinker that gave a specific interpretative twist to the theme of progress, addressing it from the perspective of the economy. This aspect of Marx's writings is therefore for Balibar (1995) marred by-mainly economic-determinism and finalism, despite the fact that Marx envisaged a state-of-affairs that would ultimately break with the logic of historical development, i.e., the classless society that would signify the emergence of history proper, i.e., history qua freedom (p. 94).

However, Balibar thinks he can still trace a non-determinist Marx that focuses on historicity and in human practice rather than on universal historical trends, in reading between the lines of Marx's major works cited above and in light of some remarks contained in his Critique of the Gotha Program and his correspondence with Vera Zasulich. Balibar even claims that by "an astonishing turnabout," Marx's "economism gave birth to its opposite: a set of anti-evolutionist hypotheses" (Balibar, 1995, p. 108). In any case, even if we accept Balibar's argument, Marx presents us with a limit-case of a thinker who was both fascinated with the mixture of positivist and progressive accounts of his times and had an intimation of intellectual developments that were yet to emerge. Or, in yet another formulation, on the one hand, Marx appears as "the supreme rebel against bourgeois liberal thought" and on the other hand Marx "accepted universalism in so far as he accepted the idea of an inevitable historical march toward progress" (Wallerstein, 1991, p. 125).

Arguably, the development of the idea of progress in modernity was shaped to a certain extent by the combination of medieval 
eschatology and the emergence of expectations made possible by a host of unprecedented changes in science and political, economic and social institutions. Indeed, Koselleck claims that this combination produced a temporality, which could open up to the future without limit, thereby making possible the very idea of universal history (see Koselleck, 2004, p. 140, 232). Of great importance is Koselleck's insight that progress was not "simply an ideological mode of viewing the future" but that it "corresponded, rather to a new everyday experience which was fed continually from a number of sources," such as the developments of technical civilization and the rapid changes of social and political institutions (Koselleck, 2004, p. 60). Now it has to be noted that although the meaning of the concept of ideology remains largely ambivalent, ${ }^{3}$ we should certainly take care not to treat the idea of progress as epiphenomenon. In this sense, progress should be best understood as an "imaginary social signification" in the sense that Castoriadis gives to this concept, viz. as a signification that is neither limited to the perceived (real) or to the consciously thought, but stemming from the unconscious forms the unacknowledged ground of collective and individual practices and actions (see, e.g., Castoriadis, 1987, esp. chapters 3, 4, 7; for a detailed discussion of the concept, see Arnason, 2014).

Alternatively, we could treat progress as a key element of what Taylor calls "social imaginary," viz. a pre-theoretical, relatively structured manner of understanding the world, shared by large social groups or even whole social formations, informing practices and granting legitimacy to actions and institutions ${ }^{4}$ (see, e.g., Taylor, 2007, p. 172-173).

Fukuyama traces the emergence of the specifically modern conception of progress on the writings of Machiavelli and especially in what he understands as a decoupling of politics and

\footnotetext{
${ }^{3}$ The problem is quite complex to adequately discuss it here. Suffice it to say that a host of developments in epistemology and the theory of knowledge in the twentieth century render the class-laden and clear-cut conception of ideology as distorted consciousness propounded by Marxism rather untenable. Mannheim's treatment of ideology and utopia as an inseparable couplet and the abolition of the distinction between truth and ideological distortion in favor of an understanding of knowledge as relational (with the exception of mathematics and the natural sciences) and always already linked to specific Weltanschauungen bound to social groups (see Burger and Luckmann, 1971, p. 21-22), the so-called linguistic turn, phenomenology's insistence on the lifeworld as the ground of scientific discourses, Foucault's treatment of the couplet episteme/science and the linking of meaning with "discursive formations" in his two major epistemological works, are but few instances of the challenges to the customary understanding of ideology. This does not make the concept of ideology redundant, for such an attitude would cancel any claims to truth and would render impossible the very foundation of reason, viz. its critical function. We are just compelled to try to establish a more subtle understanding of ideology as an inescapable element of the hermeneutic condition, or as Ricoeur puts it, once we have rejected the possibility of a total view of the social world, we have to cultivate our "practical wisdom" in the knowledge that we "cannot get out of the circle of ideology and utopia" and to use critical reason to turn this circle into a "spiral" (Ricoeur, 1986, p. 314).

${ }^{4}$ At least two significant authors refer to progress in terms that seemingly contradict my attempt to address it as something much more complex than an easily refuted superstition. Arendt (1973) (p. 144) describes progress as superstition and Balibar (1995) as ideology. However, in my understanding, Arendt's overall analysis suggests that she does not treat it like an epiphenomenon and the same holds for Balibar, who using "Canguilhem's terminology" links evolutionism as "scientific ideology" with the emergence of a "site of exchange between scientific research programmes and the theoretical and social imaginary" (Balibar, 1995, p. 91-emphasis added).
}

morality in Machiavelli's works. The same author traces important formulations of progress in the writings of Enlightenment thinkers like Voltaire, the encyclopedists and Condorcet, but suggests that it is with the emergence of German Idealism that the notion was given the most thorough and "serious" treatment (Fukuyama, 1992, p. 57). Arguably, within German Idealism, progress was seen primarily in terms of the gradual attainment of truth as in Kant's ideal of gradual Enlightenment and Hegel's conception of (absolute) spirit.

Kant has been often considered as providing us with a moderate and yet somehow canonical conception of the Enlightenment and of the theme of progress in history. In his treatment of Kant's writings that directly or indirectly deal with the problem of progress and history, Honneth discerns three distinct modes under which Kant tackled this issue. The first such version is arguably largely dependent on Rousseau's view of civilization and therefore woven around the concept of "unsocial sociability" and the need for recognition from one's social environment (Honneth, 2009, p. 12). The second version postulates that social conflict in the guise of the constant threat of war and the perpetual attempts to put an end to conflict provide the main mechanism of progress in history (Honneth, 2009, p. 13).

In Honneth's view, both versions mentioned above rely on the assumption that a common teleology bridges the natural and the human realms and it is only with the third version that the specifically human domain is seen as relatively independent of natural teleology. As he puts it, the third version envisages nature only as the "origin of a specific human capacity... and not as the original cause of a plan that concerns us" (Honneth, 2009, p. 14). At first glance Kant's third formulation might look less important than it really is. Honneth traces therein the insight that human intelligence and "the mechanism of learning" is established as the key-mechanism of progress both ontogenetically and phylogenetically and claims that there are similarities between Kant's and Hegel's treatment of progress; in his view, they both understand historical processes in terms of "directed progress," with the crucial difference that Kant did not rely to the "anonymous process of an unfolding of spirit” (Honneth, 2009, p. 17).

In a fashion that arguably brings him quite close to Habermas's understanding of the role of the public sphere and his theory concerning the emergence and development of communicative rationality, Honneth argues that it is only this last version of Kant's treatment of history that is viable and "fruitful for the present," since all those who "actively side with the moral achievements of the Enlightenment" are now to understand history as "a conflict-ridden learning process" and themselves as "heirs" of this process and therefore as responsible for the continuation of this development "in their own time" (Honneth, 2009, p. 18).

Now, I believe that we could add some elements to this insight without violating Honneth's intentions and insights. First, it has to be noted that we could always interpret Hegel's immanent teleology - and his treatment of absolute spirit—as relatively open. In this case, the elective affinities between Kant's and Hegel's versions of human freedom and historical progress become more pronounced. In this respect, it is certainly no accident that Rose who argues that in "Hegel's thought 'spirit' means the structure of recognition or misrecognition in a society" and is "inseparable 
from absolute spirit, the meaning of history as a whole," is able to trace parallels between Kant's moral judgment and Hegel's absolute ethical life (Rose, 1981, p. 41, 45).

Second, the idea of interrupted historical progress that is relatively independent of nature opens up a whole field of investigation into the ever-changing relations between the human and non-human forms of development. It should be noted in passing that in my view, of the various answers given to this problem the most promising one is Castoriadis's. According to Castoriadis society is characterized by a twofold indeterminacy: on the one hand in leaning on the "first natural substratum" society is relatively independent from what we usually call natural laws and on the other hand in being developed around magma-like social significations, institutions resist the kind of explanation that is based on what Castoriadis calls "identitary" (formal-mathematical) logic (see Castoriadis, 1987, esp. chapter 5; Clooger, 2014 shows how Castoriadis's critique of ensemblistic-identitary logic is in effect a focused and profound critique of reason).

A third point concerns the simple observation that any progress through learning could never be only contemplative in nature. Rather, any attained "truth" was to be embodied in institutions and thereof to promote both collective and individual autonomy, despite the all too often felt tension between the individual, the particular and the universal that Hegel sought to reconcile through his conception of the modern state. It goes without saying that this identification of truth, progress, and modernity was also met with resistance, the most acute moment of which in the nineteenth century is arguably to be found in Nietzsce's relegation of the status of truth to that of "metaphor" and his subsequent double assault on the idea of progress in history via the metaphor of the "eternal return of the same" in Thus Spoke Zaratustra and the postulation of the existence of retrogressive forces as founding instances and pillars of the Judeo-Christian civilization and of European modernity in The Genealogy of Morals.

\section{SOCIAL THEORY AND SOCIAL CHANGE}

However, to the extent that challenges to the Enlightenmentinspired dominant discourse on progress remained relatively limited and marginal, the imaginary of progress did not fail to capture sociological imagination ever since the inception of the discipline. Auguste Comte, this "partisan of order as well as progress" (Wernick, 2001, p. 10), thought that he had grasped the "law of the three stages" that the human spirit of necessity had to undergo in its development and he postulated relevant transformations in the domain of whole societies and institutions.

Nisbet has shown that in regard of his commitment to the idea that "human history has been linear, that it has progressed in stages or epochs, and that it resembles nothing so much as the intellectual development of a single individual," Comte is in fact a typical representative of his times and the heir of a conception that emerged in Roman Antiquity and later "seized and made the key to world history by St. Augustine" (Nisbet, 1994, p. 255). As we know, Comte's ill-fated conception (apparently an early and somehow clumsy attempt at a sociology of knowledge) was met with suspicion or even outward rejection ever since Durkheim saw as his task to purge sociology from Comte's metaphysics. ${ }^{5}$ The same suspicion was directed against Herbert Spencer's evolutionism, arguably yet another Darwin-inspired guise under which the "imaginary signification" of progress was addressed in the early days of sociology and which was pronounced over and done with by Talcott Parsons in his first major work The Structure of Social Action, ${ }^{6}$ although in a strike of irony Parsons himself came to adopt a quasi-evolutionary perspective of social change in his later works, expressed most notably in his 1964 article "Evolutionary Universals in Society" (Parsons, 1964).

Interestingly, Parsonian sociology was accused of promoting an a-historical view of society that allegedly hindered any substantial analysis of social change. ${ }^{7}$ In his 1968 postscript to The Civilizing Process, Elias gives an interesting interpretative twist to this criticism against structural functionalism. Indeed, he argues that with the introduction of the concept of "pattern variables" and especially with the couplet "affecivity vs affective neutrality," Parsons re-interprets Tönnies's distinction between Gemeinschaft and Gesellaschaft. In this reading of the Parsonian oeuvre, community is characterized by affectivity and society by affective neutrality. Elias argues further that by introducing highly abstract concepts like these, Parsons theorizes social change as if it was a "card game" and remains insensitive to the "distinguishing peculiarities" of historically specific societies (Elias, 2000, p. 453-454). According to Elias, Parsons uses concepts like "ego" and "system" in a reified manner that reproduces Durkheim's allegedly erroneous assumption that the "relation between 'individual' and

${ }^{5}$ Comte's positivist epistemology was however also heavily reliant on the idea of progress, as the "idea of the progressive filiation of the sciences is crucial to his strategy" (Nisbet, 1994, p. 254). Although it is impossible to adequately treat the place progress holds in the history of epistemology and of science in the context of this brief discussion, some comments on the issue are still in place. Positivism in general gave progress a central position as it assumed that scientific knowledge was cumulative and progressive. However, late Wittgenstein, Kuhn, and others contributed in undermining this conception. Indeed, both Wagner (2016) (p. 27) and Feyerabend emphasize the role of Kuhn's Structure of Scientific revolutions in disrupting the positivist understanding of knowledge, while Feyerabend focuses specifically on the importance of incommensurability, a notion employed by Kuhn and himself, for the undermining of what he calls the quantitative (or strong) conception of scientific progress (Feyerabend, 1987, p. 156). However, interpretations being often unpredictable, one should note that Kuhh's work has been used by Campbell in the opposite direction, viz. so as to make feasible an "operational sense of progress together with an evolutionary epistemology" (Dancy and Sosa, 2000, p. 271-272).

${ }^{6}$ See for example the opening statements of The Structure, where Spencer is declared "Dead by suicide at the hands of person or persons unknown," together with the positivist-utilitarianist tradition that according to Parsons he represents. Indeed, Parsons goes as far as to suggest that the reason of Spencer's fall from grace is none else but his adherence to the principles of evolution and progress (Parsons, 1949, p. 3-4). However, some scholars have discerned a commitment to progress even in this early work of Parsons. Indeed, they argue that Parsons ultimately holds in The Structure "a relatively unilinear notion of historical progress," while he is blind to the contradiction between "his critique of evolutionist constructions of history à la Spencer and his own interpretation of intellectual history with its implicit belief in progress" (Hans and Knöbl, 2009, p. 48-49).

${ }^{7}$ Alexander observes that the initial criticism against Parsons in relation to social change was the erroneous assumption that he lacked any theory of systemic change. However, later and "in response to the voluminous scholarly writing on differentiation," this critique gave way to the opposite but equally unjustified critical assumption that the "functionalist approach to change is, in fact, overly systemic" (Alexander, 1978, p. 183-184). 
'society' is an 'interpenetration' of the individual and the social system" (Elias, 2000, p. 456). It is this treatment of concepts that in Elias's view leads Parsons astray and is responsible for his reducing "processes to states" (Elias, 2000, p. 456).

However, in relation to progress, there are two important elements in Elias's criticism of Parsons. First, although Elias writes the postscript at a date when Parsons had already explicitly published works that focus on the theme of evolution there is no mentioning of this issue in the postscript. Instead, his critique is but a variation of the mainstream critique against structuralfunctionalism, which it accuses of holding an "Eleatic" view of society as it assumes that "societies are usually to be found in a state of equilibrium" (Elias, 2000, p. 459). Second, Elias's critique of Parsons is followed by the quite interesting suggestion that Parsons's alleged blindness to social change ${ }^{8}$ is a result of a total rejection of the theme of social development, a concept that Elias uses in this context as almost synonymous to progress. Indeed, Elias argues that this is part of a wider decline of the theme of development in the social sciences that in his view should be attributed to the contamination of nineteenth century accounts of social development such as those of Comte, Spencer, Marx, and Hobhouse by "political and philosophical ideals" (Elias, 2000, p. 458). Against that idealization of progress, the "nation" provided in Elias's interpretation of twentieth century mainstream social theory the equally ideological imagery of an unalterable substance that served as a model for structuralist-functionalist accounts (Elias, 2000, p. 462-463).

It has to be noted in this context that throughout this text Elias seems to hold the view that the social sciences should not altogether refrain from using the concept of development, or the waning "belief in progress," but that they rather have to purge it from ideological elements and ground their analysis on facts (Elias, 2000, p. 458, 461, 467). Leaving aside the epistemological difficulties this claim entails, it should be noted that it is perhaps this attitude that led some readers of his works to see Elias's treatment of civilization as evolutionism in disguise as Van Krieken (1998) observes (p. 66). This is in my view a blatant misunderstanding of Elias intentions, since he clearly understands civilization as a precarious and unfinished process, always threatened by counter-civilizing processes, ${ }^{9}$ like the "decivizing spurt of the Hitler epoch" (Elias, 1996, p. 1) as he writes in the introduction to The Germans. At the same time though, I cannot but agree with Van Krieken (1998) that there operates in Elias's work a conviction that modern societies have actually developed

\footnotetext{
${ }^{8}$ It is possible that Parsons's famous statement in The Social System that "a general theory of the processes of change of social systems is not possible in the present state of knowledge" (Parsons, 1991, p. 327), combined with the overall emphasis he placed on the notion of systemic equilibrium has led to this misinterpretation of his stance towards social change.

${ }^{9}$ Smith observes that in contrast to Hannah Arendt who understands decivilizing processes and Nazism in particular "as involving a tightening of controls," Elias describes National Socialism "in terms of a breakdown of controls" (Smith, 2001, p. 62), or we could add as a regression in the development of the German Habitus. In this respect, it is certainly no accident that Elias argues that it is "no figure of speech but a simple statement of fact to say that Hitler in Germany had a function and characteristics similar to those of a rainmaker, a witch doctor, a shaman in simpler tribal groupings" (Elias, 1996, p. 388).
}

or progressed in some aspects and in a non-linear manner (like in science and in the extended application of self-control) in relation to medieval ones (p. 67). In any case, it is strange that Elias neglects altogether to comment on the clearly evolutionist character of Parsons's later theories.

Indeed, in his later works, Parsons envisages the existence of "evolutionary universals," i.e., elements "sufficiently important to further [socio-cultural] evolution," while he argues that social organization through kinship, communication with language, religion, and technology form an indispensable and "integrated set of evolutionary universals at even the earliest human level" (Parsons, 339, 342). In another work of the same period, Parsons clearly addresses the problem of social change from an evolutionary perspective, arguing that sociocultural "evolution has proceeded by variation and differentiation from simple to progressively more complex forms," although he also insists on the plural and non-linear character of this development (Parsons, 1966, p. 2). It is this assumption that both operates behind his fundamental tripartite classification of historical societies as "primitive (sic) intermediate and modern," and informs his claim that modernity has its single historical origin in the "societies of Western Europe as they developed from the medieval base, which emerged after the decline of the Roman Empire" (Parsons, 1966, p. 3).

A response to evolutionism came in the late 1960 s from Robert Nisbet (1969), who argued against evolutionary conceptions of social change that he rightly attributed to both sociological and philosophical accounts, although his argument can be extended so as to include interpretations of social change that rely heavily on the idea of progress. Put in a nutshell, Nisbet's argument is that social theory and philosophy suffer from an unjustifiable-and ultimately ideological-conception of social change in terms of passage from allegedly lower (traditional) forms of societal life to allegedly higher ones in modernity. Importantly, he attributes the tendency of modern thought to theorize social change in this rather simplistic manner, to an interpretation that was-perhaps accidentally-given in modern times to the Greek conception of growth and decay in combination with the Aristotelian conception of entelecheia, i.e., the inner principle allegedly guiding every being toward its end or its perfection. Nisbet argues that the concept of entelecheia was reinterpreted both in the context of the Christian tradition through the writings of Saint Augustine and in the modern, secular philosophical, and sociological accounts of social change that tend to address this phenomenon as a process immanent to society and in this respect in terms of a necessary development. Nisbet also argues that the most exemplary form of this interpretation is to be found in functionalist and structuralist sociological accounts, in the context of which it also results in the hypostasization/essentialization of "society" as such.

\section{COMMUNITY/SOCIETY}

As already implied in the discussion above, the idea of progress is also hidden behind the celebrated dichotomy between community and society (Gemeischaft and Gesellschaft), which was so dear to early sociologists. Far from being just an imagery informing Ferdinand Tönnies's homonymous work, this simple opposition 
can arguably be discerned in various guises (or even in disguise) in a series of sociological discourses on the social, ranging from Max Weber's ideal-typical juxtaposition between "traditional" and "modern"/"rational" forms of social (inter) action and association in his Economy and Society, to Durkheim's postulation of two forms/modes of solidarity (mechanical and organic) corresponding to pre-modern and modern societal formations. In both cases of course, the inferences are far from direct.

Weber's understanding of modernity in terms of rationalization and disenchantment is a far cry from a celebration of progress as his "Stahlhartes Gehäuse ${ }^{10}$ " or "iron cage" thesis in the Protestant Ethic clearly shows (see Weber, 1992, p. 123). This holds insofar as this thesis expresses a great concern-if not outright distaste (see Giddens, 1992, p. xix)-for the impact of the specific forms of rationalization characteristic of European modernity in institutions and individuals alike. However, in spite of the rather unresolved tension between the unmistakable marks of Nietzsche's influence in Weber's interpretation of modernity and his endorsement of the methodological principle of value-neutrality as a prerequisite of the sociological enterprise, the eminence Weber attributes to rational action might not be accidental. In other words, as Weber's methodological atomism has been attributed to an unacknowledged commitment on his part to the modern Weltanschauung concerning individuality (see Löwith, 1993, p. 61), so it is possible that his ideal-typical typology of action bears subtle imprints of a shared understanding of modernity as progressive in terms of rationality in relation to pre-modern forms of societal organization.

A similar observation can be made in relation to Durkheim's conception of modernity and of social change. Although Durkheim intentionally reverses the meaning the terms "organic" and "mechanical" originally held in Tönnies's work, at bottom, the conception regarding the progressive character of modern societies in comparison to pre-modern ones remains intact in his conception, if it is not even more pronounced than in Tönnies's case. Durkheim theorizes modernity-and social change-in terms of passage(s) from states-of-affairs that fall under the category of "mechanical solidarity" to states-of-affairs that are mostly characterized by "organic solidarity," i.e., with forms of social life that are compatible with a higher sense of individuality. Müller rightly observes that Durkheim's use of the term solidarity should be understood as an attempt to cast a "relational" concept that would adequately grasp the nature of the social bond and give an answer to the problem of social order. Mechanical solidarity

\footnotetext{
${ }^{10} \mathrm{Baehr}$ argues that Parsons violated the meaning of this phrase when he chose to translate it as "iron cage" instead of "shell as hard as steel" as Baehr (2002) himself proposes (p. 200). In Baehr's interpretation of the Protestant Ethic, this phrase would best capture Weber's quasi-Nietzschean insight concerning a radical shift in the human condition, the emergence in modernity of some unprecedented mode of passivity of humans vis-à-vis their own creations. Baehr rightly observes that although Weber did not partake in the "parody" of kulrurpessimismus that was quite popular at his times, he was still troubled and "disconsolate about the human prospect" at least with regard to the Occident (Baehr, 2002, p. 197). It should be noted, however, that the concept of Stahlhartes Gehäuse does not simply signify the coercive elements of rationalization, since "its unparalleled rational and technical efficiency provided the essential services and goods of mass consumption" that few modern individuals "would willingly" dismiss (Gosh, 2014, p. 389).
}

thus describes a form of direct integration of the individual in community, while organic solidarity expresses integration via increasing differentiation of both the levels of individual existence and the collective representations than become much more complex than in simple and archaic forms of societies (Müller, 1994, p. 79).

Now this could be-and has been-interpreted in different ways. Nisbet argues that Durkheim was one of the few intellectuals of his generation that resisted the idea of moral progress, but he also stresses the purposive use on Durkheim's part of Tönnis's distinction between Gemeinschaft and Gesellschaft, his adherence to the theses of "social atomization" and "secularization" (Nisbet, 1965, p. 18, 21-22). However, at the other end of the spectrum of possible interpretations, the precarious-and perhaps even deceptive-character of this distinction has been rightly highlighted by Jean-Luc Nancy in his celebrated collection of articles bearing the telling title The Innoperative Community. In this work, Nancy argues against the allegedly fictive character of the distinction as he remarks that "community has not taken place... or rather...community has never taken place along the lines of our projections of it," and consequently no "Gesellschaft has come along to help the State, industry, and capital dissolve a prior Gemeinschaft" (Nancy, 1991, p. 11).

Moreover, the entanglement between the idea of progress and the imagery of the passage from community to society could also be discerned in the functionalist conception of social change in terms of (social) complexity and (systemic) differentiation. ${ }^{11}$ Providing at the same breath an account and a self-understanding of modernity, this fundamental differentiation between community and society essentially informs even more recent and more sophisticated approaches, such as Habermas's Theory of Communicative Action, where a main differentiation is drawn between systems and communicative lifeworld(s).

The possibility of multi-dimensional lifeworlds was already acknowledged in Alfred Schutz's classic The Phenomenology of the Social World, where it is clearly stated that the lifeworld is open to differing and perhaps conflicting interpretations, and the author offers the "examples" of the magical interpretation pertaining to simple societies, the theological interpretation of the sort propagated by a religious missionary and the scientific one corresponding to the modern scientist (Schutz, 1966, p. 270). Apart from bearing some uncanny similarities with Comte's "law of three stages," Schutz's conception here seems to be premised on the belief that lifeworlds are in a process of gradual 
rationalization, a thesis associated with the writings of Max Weber but clearly presented and defended by Habermas in the Theory of Communicative Action (see also Wagner, 2016, p. 88).

\section{SYSTEMS AND LIFEWORLDS}

Habermas attributes both ontological and epistemological primacy to the lifeworld, which he treats as the original locus of social interaction and as the foundation of systemic forms of social development (see Joas, 1991, p. 114). He is therefore at pains to establish beyond doubt the-allegedly historically confirmed-thesis of the gradual rationalization of the lifeworld, in an attempt to provide at the same time a comprehensive argument concerning the mechanisms of social change, a grounding of his concept of "communicative rationality" and of the autonomy of Reason over against its various distortions that in his view are the outcome of system-related interests.

It is well known that Habermas treats the lifeword as a concept that counters the notion of the "transcendental subject," and consequently as the exemplary "transcendental" locus of communicative exchanges (and interactions) between more or less rational agents and as the place where mutual agreement is to be sought and social consensus could ideally be attained (Habermas, 1987 , p. 126-127). He furthermore maintains that seen from the "inner" perspective of agents, the lifeworld is a concept that presents elective affinities with Durkheim's concept of "collective consciousness" (Habermas, 1987, p. 133). In this sense, the lifeworld forms the meaningful horizon within which agents live and interact and on which rest both the meaningful orientation of their individual actions and the overall vestige with meaning of whole societal formations. Like an horizon proper, the lifeworld cannot itself become a theme of the subject's consciousness (Habermas, 1987, p. 124) and consequently its various objectifications (like for example in cases of forms of culture, etc.) only reveal aspects of its overall structure. Habermas's argument is way too complex to be dealt with in detail here, it is however important to note that despite acknowledging the impact intricate interactions between competent but possibly non-expert (or lay) agents has on the very outlook and structure of specific lifeworlds, he still believes that overall the structural and morphological transformations of lifeworlds can be interpreted as a process of gradual transformation of "the sacred into language."

This conception, which again reproduces one of Durkheim's most celebrated distinctions (i.e., that between the sacred and the secular), arguably identifies the "sacred" with the "ineffable" (in the sense of something quasi-mythical, imaginary but nonyet explicitly linguistically expressed) and the secular with the linguistically mediated and gradually developed rationality. In Habermas's view, the internal differentiation of the lifeworld results in the proliferation of "regions," where interaction takes place under conditions of a mutual orientation toward understanding and where the attainment of consensus depends on the principle of the "best argument" (Habermas, 1987, p. 145).

This formulation entails a double defense of the autonomy of reason against the criticisms of the first generation of the Frankfurt School and especially against the celebrated thesis of The Dialectic of Enlightenment (a reversal itself of the Hegelian and Marxian version of dialectics), and according to which far from reaching an Absolute self-clarity (as in Hegel) or a fully emancipated state-of affairs (as in Marx), "enlightened" reason (the Ratio) of necessity relapses to myth and unreason as it follows an inconclusive and vicious dialectic. The Dialectic of Enlightenment is a fine example of theoretical discourses criticizing the idea of modernity as progress, which-unlike other critiques of modernity as for example Spengler's Decline of western Civilization-retains a certain commitment to the ideals of human emancipation and reason, ${ }^{12}$ while tending to interpret modernity from the perspective of regression (though not of decay).

In this respect, on the one hand, Habermas's conception of gradually rationalized lifeworlds stands in stark contrast to Adorno and Horkheimer's (Adorno and Horkheimer, 1986) argument ${ }^{13}$ that enlightened reason is essentially instrumental and quasi-mythical, since Habermas claims that through communicative actions myth is in the last instance gradually replaced by reason on the very soil on which myth itself first emerged, viz. in the lifeworld.

Habermas offers a telling example when he claims that we can discern symbolic elements and rituals in archaic forms of society, but although these archaic, mythical forms of understanding are crucial for the emergence and maintenance of social integration, they merely inform social behavior, not action proper. Rather, he explicitly states that only through the "transformation of primitive (sic) systems of calls into grammatically regulated, propositionally differentiated speech was the sociocultural point reached at which ritualized behavior changed into ritualized action" and that from that point on "we no longer have to be content with describing ritualized behavior [but] we can try to understand rituals" (Habermas, 1987, p. 190). In other words, this largely fictive-but perhaps heuristically fruitful-postulation of a major transformation in the midst of mythical representations of the world reproduces the widely shared conviction that reason has myth as its foundation and that human action is only conceivable as such under conditions of relative rationalization. It follows that our attempts to "understand" action in the manner of the Weberian Verstehendesoziologie are only conceivable under conditions of some emergent form of rationality-the reinterpretation on Habermas's part of Weber's typology of action-and especially of Weber's conviction that "emotional" and "traditional" actions are not actions proper, being in my view more than evident here.

\footnotetext{
${ }^{12}$ According to Alexander, an extreme example of the critique of reason is presented in the writings of Sorel, who "faced with the disappointment of his socialist hopes for progress" came to propound the idea "that individuals are not as rational as progressive theory had thought." Indeed, he even attempted to establish "a commonality between modern actors and the myth worshipers of traditional societies" and wavered himself "between revolutionary left and right" (Alexander, 1990, p. 22).

${ }^{13}$ Habermas claims that in The Dialectic of Enlightenment Horkheimer and Adorno "play a variation on the well-known theme of Max Weber, who sees the ancient, disenchanted gods rising from their graves in the guise of depersonalized forces to resume the irreconcilable struggles between the demons" (Habermas, 1990, p 110). Importantly, Habermas also sees the central thesis of the Dialectic as equally perilous or "no less risky than Nietzsche's similarly posed diagnosis of nihilism" (Habermas, 1990, p. 110).
} 
On the other hand, Habermas traces a direct link between the distortive elements of reason (the so-called instrumental rationality) and systemically grounded interests. In this sense, he attempts to differentiate between a non-distorted, communicative form of rationality emerging progressively out of the development of the lifeworld(s) and a potentially alienating form of rationality generated by systemic differentiation and the proliferation of systems. In other words, he claims that these ideal-typical representations of societies (i.e., system and lifeworld) undergo a series of changes that he calls the gradual "uncoupling of systems and lifeworld" (Habermas, 1987, p. 153), and which results in the perilous "colonization" of the lifeword by systemic interests under the influence of media like money and power, i.e., in the progressive technicization and instrumentalization of the lifeworld's symbolic structures (e.g., Habermas, 1987, p. 183, 187, 196).

Habermas's critique of systems follows his earlier attempts to come up with a critique of instrumental reason without denying altogether the emancipatory powers of reason and science, to be found most notably in his Reason and Human Interests. It can also be interpreted as a critique of the so-called "modernization theories" based on models of economic growth (rather than development), since Habermas treats economic systems largely as obstacles to the attainment of social consensus on the grounds of undistorted communication.

\section{PROGRESS AND PLURALITY: BEYOND MULTIPLE MODERNITIES?}

A further critique of modernization theories was advanced by Shmuel Eisenstadt's "multiple modernities" approach, which was based on a reinterpretation of Karl Jaspers's "axial age" thesis. Ironically, Eisenstadt's writings in the 1950s still presented but "an unorthodox version" of modernization theories and his most prominent work in the 1960s, his comparative study of World Empires, was conducted within the theoretical framework of Parsons's systems theory. Arnason observes that this prevented Eisenstadt from making the most out of the diversity of his material, since the imposition of "predicated on an evolution from simple to complex societies" prevented him from completing his critique of modernization accounts (Arnason, 2015, p. 148-149).

No single work of Eisenstadt adequately develops the theoretical framework of his later work that came to be known as "multiple modernities" and which Arnason describes as a "cultural turn" in Eisensatdt's approach to socio-historical phenomena. However, his break with the Parsonian paradigm is attributed to at least two main factors: First, Eisenstadt was increasingly convinced that the state of Israel presented the unique manifestation of the modern project. Second, this insight was further enriched by Eisenstadt's reinterpretation of Karl Jaspers's "axial age" thesis and the concept of "axial civilizations" (Arnason, 2015, p. 165-166).

According to the "multiple modernities" approach, the great Eurasian civilizations of the first millenium (700-400) B.C.E, i.e., of the "axial age," shared the emergence of certain characteristics that mark the passage from pre-history to history and are still relevant today. The most important elements are the differentiation between the "sacred" and the "secular" spheres and the emergence in some cases of the first "world religions," the emergence of reflexivity (and philosophy), a primal understanding of human historicity and the acknowledgment of human agency as a crucial historical factor, or as Wagner puts it, the acknowledgment that "a different world is possible" (Wagner, 2005, p. 93; Wittrock, 2005 , p. $61 \mathrm{ff}$.). The merit of this approach is that it attempts to address modernity under a pluralistic perspective, as a history of continuous processes of formation and transformation of what Eisenstadt (2000) calls "cultural programmes," a term coined to substitute for the notions of "civilizations" and "societies" (p. 2 ). Therefore, it resists both the urge to theorize modernity in one-dimensional manner (say as conditioned by developments in the economy) and to some extent the tendency to understand modernity through the over-simplistic conception of the passage $^{14}$ from medieval times to modern ones.

Eisensatdt understands modernity as a "distinct civilization with distinct institutional and cultural characteristics," as a "crystallization" of "modes of interpretation of the world," or as forming a distinct social imaginary, as he writes following Castoriadis (Eisenstadt, 2002, p. 28).

The multiple modernities approach is explicitly directed against Fukuyama's assumption concerning the alleged lack of alternatives to the established socio-economic and political institutions of capitalism that became popular under the rubric of the "end of history." It was also consciously developed against the Samuel P. Huntington's conflict-laden interpretation of western and non-western civilizations (Eisenstadt, 2002, p. 27). In this respect, it challenges to a considerable degree the assumption that social change could be theorized in general from the standpoint of progress or evolution and that this progress is represented by the specific progression of cultural, social, scientific, economic, and political institutions in the western world. However, it has been also pointed out that the idea of an almost "direct" link between the axial age and our "present era" is rather unsustainable (Wagner, 2012, p. 156), while the very emphasis of the "multiple modernities" approach to reflexivity, historicity, and agency could be seen as uncritically reproducing mainstream conceptions of modernity (Wagner, 2005, p. 104).

In response to these problems, Wagner has proposed in his Modernity as Experience and Interpretation (Wagner, 2008) and in his subsequent works to study modernity from the perspective of at least three fundamental problématiques (viz. the epistemic, the political, and the economic) without privileging a priori any of them and secondly, to substitute of the term "improvement over time" for the notion of "progress" (Wagner, 2012, p. 151). In the same vein, he proposes to avoid if possible the overburdened with meaning terms "society" and "civilization" and to replace them with more fluid and indeterminate notion of "collective self-understanding” (Wagner, 2012, p. 158). Wagner's proposal is interesting as far as our often misleading concepts of society,

${ }^{14}$ It is worth noticing that Wallerstein adds some significant remarks to this critical point, even as he writes from a quite distinct theoretical perspective to that of multiple modernities. Indeed, Wallerstein links the very notion of "transition" to the fallacious idea that "history is progressive, and inevitably so" and to the tendency of the social sciences to study what he calls "historical systems" under the theoretical pattern of "linear transformations" (Wallerstein, 1987, p. 322-323). 
civilization, and progress are concerned, but a lot of conceptual labor is required before we could feel content with the ways in which the very impasses resulting by the modern and contemporary understandings of collectivity, subjectivity, and identity could be overcome. In effect, the notion of "improvement over time" has the merit that it retains a "weak" ideal of progress while attempting to break with the commitment to the idea of immanent development and entelecheia in the sense discussed above. The same goes for Wagner's attempt to substitute the notion of "physical human beings" for the more conventional notion of the "subject," although it has to be noted that the proposed term is no more tangible and no less metaphysical than the alternatives, while it presupposes a great deal of groundwork on key concepts like the body, the self, being, etc. before we could possibly use it in a satisfactory manner.

However, the indisputable merit of Wagner's aforementioned proposal is that it thematizes the problems generated by the link between conceptions of modernity and the idea of progress, it provides us with alternative ways of theorizing modernity and in so doing it also shows the possible inescapability of the question of progress. The link between modernity and progress becomes certainly less visible in discourses that extrapolate a radical discontinuity between modernity and post-modernity like in Lyotard's The Postmodern Condition ${ }^{15}$ that drew on and extended "the earlier thesis about post-industrial society" and emphasized "the impact of new information and communication technologies" (Wagner, 2015, p. 107), or with discourses that attempt to altogether deconstruct western metaphysics and consequently also the modern preoccupation with progress. However, in their origins, deconstructive discourses often fail to resist the temptation to exaggerate the aspect of decline ${ }^{16}$ as in Nietzsche's assumption that counter-creative forms of power were constituent of the nineteenth Century European civilization, or Heidegger's claim that technology forms the ultimate horizon of western metaphysics, barring alternative manifestations of common and individual being. ${ }^{17}$

Since at least 2008, Wagner's works have increasingly penetrated the thorny question of progress and his last published

\footnotetext{
${ }^{15}$ Lytotard argues that in postmodernity grand narratives have lost their legitimation: "The grand narrative has lost its credibility, regardless of what mode of unification it uses, regardless of whether it is a speculative narrative or a narrative of emancipation" (Lyotard, 1984, p. 37).

${ }^{16}$ Expectedly, interpretations on this issue vary. Nehamas for example argues that we miss the ambivalence of Nietzsche's attitude towards modernity if we simply see it in terms of the theme that Alan Bloom described as the decline of the West (Nehamas, 1996, p. 223, 245). In any case, even a more moderate interpretation of these philosophers' attitudes towards modernity, could hardly miss a crucial aspect of their-otherwise divergent-philosophical projects. Indeed, it is indisputable that Nietzsche and Heidegger "distance themselves from the foundational claims of the Enlightenment" and in so doing, they also "abandon the notion of "critical overcoming' so central to the Enlightenment critique of dogma" (Giddens, 1991, p. 47). This means though that their works have also contributed at least to a radicalization of the questioning of the very idea of progress.

${ }^{17}$ This claim is quite clearly formulated in the following sentence: "The threat to man does not come in the first instance from the potentially lethal machines and apparatus of technology. The actual threat has already afflicted man in his essence. The rule of enframing threatens man with the possibility that it could be denied to him to enter into a more original revealing and hence to experience the call of a more primordial truth" (Heidegger, 1993, p. 333).
}

book on the issue (2016) is such a response, an attempt to inhabit the space opened up between the extreme faith in progress of the eighteenth and nineteenth centuries and the disillusionment with progress that characterizes much of the twentieth century and the present. Wagner acknowledges the different dimensions of progress and the variety of interpretations historically given to this notion, as well as what-following Gadamer ${ }^{18}$ - we could call the "problem of application," i.e., the fact that there is always a dynamic between interpretation and putting a "concept into practice" (Wagner, 2016, p. 10). Indeed, in order to do justice to this complex constellation of meanings, practices, institutions, societal and political formations and individuals, he examines his material in accordance with the three problématiques mentioned above (Wagner, 2016, p. 13-14).

Wagner argues that a common "mechanism" operates behind conceptions, imageries, practices, and institutional advancements in relation to progress in the fields of science/knowledge and the economy, where the imaginary signification of "mastery" seems to accompany that of progress (Wagner, 2016, p. 38). In this respect, Wagner's reconstructive project is quite influenced by Castoriadis's well-known thesis that modernity is grounded on two-often conflicting but also entangled-core imaginary significations, viz. the unlimited expansion of "rational mastery" and political "autonomy" (Castoriadis, 1997, p. 37).

In my understanding of Wagner's work, this influence by Castoriadis's interpretation of autonomy accounts for the specific emphasis placed on the political problématique ${ }^{19}$ and for his insight that "one key concern of our time should be political progress" in the sense of a "radical commitment to democratic

\footnotetext{
${ }^{18}$ In his most prominent work, Truth and Method, Gadamer reinstates the moment of application as one of the constitutive moments of the event of understanding. He therefore argues that "historical hermeneutics too has the task of application to perform, because it too serves applicable meaning, in that it explicitly and consciously bridges the temporal distance that separates the interpreter from the text and overcomes the alienation of meaning that the text has undergone" (Gadamer, 1989, p. 311).

${ }^{19}$ The impact of progress on the shaping of political discourses is immense and impossible to adequately discuss in the context of this brief excursus. However, it should be noted that even after the disenchantment with "progress" that gradually befell western societies during the 1980s the social imaginary is still fueled by interpretations of this concept in many respects. Right-wing and populist movements have exploited the idea of progress at least in two different ways. First, they used the widespread social dissatisfaction and fragmentation of post-industria societies to attack basic democratic principles. Second, right-wing parties came up with their own appropriations of progress, as is evident in the case of the extreme right-wing Progress Parties in Denmark and Norway (Betz, 1994). The picture becomes much more complex if we take into account the argument that postindustrial societies have undergone a "silent" shift towards post-material values such as "cosmopolitanism and multiculturalism" and to political relevant skills, mainly endorsed by left-wing parties and leftist social movements (Inglegart and Norris, 2016, p. 3; Ingelhart, 1977, p. 3, 43-45) and that in this respect much of right-wing rhetoric revolves around the attempt to undermine these values. Of course, the disenchantment with progress was not merely reflected in right-wing political parties, as for example the Green Party in Germany built its identity in opposition to the notion of economic and technical progress that was part of the agenda of the established parties in West Germany at that time (Betz, 1991, p. 82). It goes without saying that in countries with different cultural economic and political background from Europe and the USA like South Africa, Brazil, etc. "Progress" has been also appropriated in a constructive manner to enhance democratic rights (Wagner, 2016, p. 62).
} 
agency" (Wagner, 2016, p. 21). Wagner casts this insight in various other ways, as for example in terms of the need to both acknowledge and actively rekindle what he calls "historical temporality." Temporality here signifies the acknowledgment of the always dynamic and precarious of the social-historical, or a state-of-affairs characterized by a tension between "abstract and 'presentist' concepts of the individual and the collectivity" and the various actual experiences of "domination and injustice" (Wagner, 2016, p. 128).

Here again, Wagner uses the experiences gained by the various "protest" social movements that emerged in the 1960s and stresses the need to renegotiate social and political forms of progress, while avoiding the extremities of what he calls "hybristic projects of radical transformation" without however rejecting also any kernel of truth they might possess (Wagner, 2016, p. $103,150-152)$. Indeed, if "critique and protest" fuel the search for "normatively superior solutions," then Wagner is right in placing great emphasis in the role of protest movements, such as the anticolonial movement, the feminist movement, and the movement against the apartheid in South Africa in the reinterpretation of the notion of progress and in the dissolution of organized modernity (Wagner, 2016, p. 108-115).

Put in a nutshell, Wagner identifies the main "mechanism" of progress from mid-eighteenth century to the last part of the twentieth century to be domination and resistance to domination, and he insists that the notion of progress should not be altogether rejected but that it should rather be replaced with a relative conception of progress through a reworking of the Enlightenment idea of collective and personal autonomy (Wagner, 2016, p. 152).

\section{SOME CONCLUDING REMARKS}

"There is no want in our age of declarations by historians and other intellectuals that the idea of progress 'died with Herbert Spencer,' 'ended with the nineteenth century', and was 'banished forever by World War I'... But the truth lies elsewhere," writes Nisbet in 1980 and goes on to argue that in spite of the abundance and variety of challenges to the idea of progress in the twentieth century, "the dogma of progress isn't at death's door” (Nisbet, 1994, p. 297). Almost 30 years later and despite the worldwide proliferation of

\section{REFERENCES}

Adorno, T., and Horkheimer, M. (1986). The Dialectic of Enlightenment, 2nd Edn. London, New York: Verso.

Alexander, J. C. (1978). Formal and substantive voluntarism in the work of Talcott Parsons: a theoretical and ideological reinterpretation. Am. Sociol. Rev. 43, 177-198. doi:10.2307/2094698

Alexander, J. C. (1990). "Between progress and apocalypse: social theory and the dream of reason in the twentieth century," in Rethinking Progress: Movements, Forces and Ideas at the End of the $20^{\text {th }}$ Century, eds C. A. Jeffrey and P. Sztompka (Boston: Unwin Hyman), 15-38.

Arendt, H. (1973). The Origins of Totalitarianism. San Diego, New York, London: Harcourt Brace.

Arnason, J. P. (2014). “Imaginary significations," in Cornelius Castoriadis: KeyConcepts, ed. S. Adams (London, New York: Bloomsbury), 23-42.

Arnason, J. P. (2015). Elias and Eisenstadt: the multiple meanings of civilization. Soc. Imaginaries 1, 146-176. doi:10.5840/si20151221 such challenges in the present, progress and decline are arguably hardly extinguished from the imaginary of contemporary philosophy and science as this brief essay attempted to show.

Since I was primarily interested in showing the ways in which the theme of progress has shaped social theory and especially theories of social change, only indirectly_and in passing-did I address the normative aspect of the relation between the various projects that could be characterized in some way as "modern" and progress. It is, however, evident that much of the discussion concerning the inescapability of the question of progress points exactly to the need to further clarify this dimension. Admittedly, this is a quite complex issue that involves a thorough discussion of many contemporary currents of thought, while it involves important epistemological and philosophical issues to which one should dedicate a separate study. In this respect, Wagner's approach is quite promising in directly focusing on the theme of progress and in showing from yet another perspective the need for a reinterpretation of the "project" of the Enlightenment. It was clear to Nisbet and it is perhaps even clearer today that a naive, unqualified belief in progress is unsustainable. At the same time, we need to take heed of Wagner's insight that a total rejection of the notion of progress might prove perilous for the social and political future of the world, or of Nisbet's claim that "in its oldest and broadest," the idea of progress "has been associated more often with good than with evil" (Nisbet, 1994, p. 318).

Irrespective of whether we understand the origins of progress to lie in Greco-Roman Antiquity (Nisbet, 1994, p. 11), or if we address it as a uniquely modern imagery, it is very difficult to completely dissociate the multiple forms of modernity from progress. Indeed, progress presents us with yet novel challenges both on the level of theory and on the various other dimensions of the social world(s), challenges to which we have to respond. The various critiques of reason and social developments worldwide have clearly undermined the belief in the universality of reason, making any attempt at reinterpretation of the basic tenets of the Enlightenment and of reason both precarious and necessary.

\section{AUTHOR CONTRIBUTIONS}

The author confirms being the sole contributor of this work and approved it for publication.

Baehr, P. (2002). Founders, Classics, Canons. New Brunswick, London: Transaction Publishers.

Balibar, É. (1995). in The Philosophy of Marx, trans. C. Turner (London, New York: Verso). Betz, H.-G. (1991). Postmodern Politics in Germany: The Politics of Resentment. London: MacMillan.

Betz, H.-G. (1994). Radical Right-Wing Populism in Western Europe. London: MacMillan. Burger, P., and Luckmann, T. (1971). The Social Construction of Reality: A Treatise in the Sociology of Knowledge. London: Penguin Books.

Castoriadis, C. (1987). in The Imaginary Institution of Society, trans. K. Blamey (Cambridge, MA: MIT Press).

Castoriadis, C. (1997). “The Retreat from autonomy," in Cornelius Castoriadis: World in Fragments, ed. D. A. Curtis (Stanford, CA: Stanford University Press), 32-43.

Castoriadis, C., and Ricoeur, P. (2016). in Dialogue sur l' histoire et l' imaginaire social, ed. J. Michel (Paris: EHESS).

Clooger, J. (2014). "Ensemblistic-identitary logic (enseidic logic)," in Cornelius Castoriadis: Key-Concepts, ed. S. Adams (London, New York: Bloomsbury), 107-116. 
Dancy, J., and Sosa, E. (2000). A Companion to Epistemology. Oxford: Blackwell.

Eisenstadt, S. N. (2000). Multiple MODERNITIES. Daedalus 229, 1-29.

Eisenstadt, S. N. (2002). "Some observations on multiple modernities," in Reflections on Multiple Modernities: European, Chinese and Other Interpretations, eds D. Sachsenmaier, J. Riedel, and S. N. Eisenstadt (Leiden: Brill).

Elias, N. (1996). in The Germans: Power Struggles and the Development of Habitus in the Nineteenth and Twentieth Centuries, trans. E. Dunning and S. Mennell (New York: Columbia University Press).

Elias, N. (2000). in The Civilizing Process: Sociogenetic and Psychogenetic Investigations, Revised Edn, trans. E. Jephcott, E. Dunning, and S. Mennell (Oxford: Blackwell).

Feyerabend, P. (1987). Farewell to Reason. London, New York: Verso.

Fukuyama, F. (1992). The end of history and the last man. New York: The Free Press.

Gadamer, H.-G. (1989). in Truth and Method, 2nd Edn, trans. J. Weinsheimer and D. G. Marshall (London: Sheed and Ward).

Giddens, A. (1991). The Consequences of Modernity. Cambridge: Polity Press.

Giddens, A. (1992). "Introduction., in Max Weber," in The Protestant Ethic and the Spirit of Capitalism, ed. T. Parsons (London, New York: Routledge), vii-xxiv.

Gosh, P. (2014). Max Weber and 'The Protestant Ethic': Twin Histories. Oxford: Oxford University Press.

Habermas, J.(1987). in The Theory of Communicative Action, Vol. 2, ed. T. McCarthy (Boston: Beacon Press).

Habermas, J. (1990). in The Philosophical Discourse of Modernity, ed. F. Laerence (Cambridge: Polity Press).

Hans, J., and Knöbl, W. (2009). in Social Theory: Twenty Introductory Lectures, ed. A. Skinner (Cambridge: Cambridge University Press).

Heidegger, M. (1993). "The question concerning technology," in Martin Heidegger: Basic Writings, ed. D. F. Krell (London: Routledge), 307-341.

Honneth, A. (2009). in Pathologies of Reason, trans. J. Ingram and others (New York: Columbia University Press).

Ingelhart, R. F. (1977). The Silent Revolution: Changing Values and Political Styles Among Western Publics. Princeton, NJ: Princeton University Press.

Inglegart, R. F., and Norris, P. (2016). "Trump, Brexit and the rise of populism: economic have-nots and cultural backlash," in HKS Faculty Research Working Paper Series. Available at: https://research.hks.harvard.edu/publications/ workingpapers/Index.aspx

Joas, H. (1991). "The unhappy marriage of hermeneutics and functionalism," in Communicative Action: Essays on Jürgen Habermas's the Theory of Communicative Action, trans. A. Honneth and H. Joas (Cambridge, MA: The MIT Press), 97-118.

Koselleck, R. (2004). in Futures Past: On the Semantics of Historical Time, ed. T. Keith (New York: Columbia University Press).

Löwith, K. (1949). Meaning in History. Chicago, London: The University of Chicago Press.

Löwith, K. (1993). in Max Weber and Karl Marx, ed. B. S. Turner (London, New York: Routledge).

Lucaks, G. (1972). in History and Class Consciousness: Studies in Marxist Dialectics, trans. R. Livingstone (Cambridge, MA: MIT Press).

Luhmann, N. (1995). in Social Systems, trans. J. Bednarz Jr. and D. Baecker (Stanford, CA: Stanford University Press).

Lyotard, J.F. (1984). in The Postmodern Condition: A Report on Knowledge, trans. G. Bennington and B. Massumi (Manchester: Manchester University Press).

Müller, H.-P. (1994). Social differentiation and organic solidarity: the 'division of labor'. Sociol Forum (Randolph N. J.) 9, 73-86. doi:10.1007/ BF01507706

Nancy, J.-L. (1991). in The Inoperative Community, ed. P. Connor; trans. P. Connor, L. Garbus, M. Holland, and S. Sawhney (Minneapolis, Oxford: University of Minnesota Press).
Nehamas, A. (1996). "Nietzsche, modernity, aestheticism," in The Cambridge Companion to Nietzsche, eds B. Magnus and K. M. Higgins (Cambridge: Cambridge University Press), 223-251.

Nisbet, R. A. (1965). "Émil Durkheim," in Émil Durkheim, ed. R. A. Nisbet (New Jersey: Prentice-Hall), 9-102.

Nisbet, R. (1969). Social Change and History: Aspects of the Western Theory of Development. Oxford: Oxford University Press.

Nisbet, R. (1994). History of the Idea of Progress. New Brunswick, London: Transaction Publishers.

Parsons, T. (1949). The Structure of Social Action. New York, London: Free Press.

Parsons, T. (1964). Evolutionary universals in society. Am. Sociol. Rev. 29, 339-357. doi:10.2307/2091479

Parsons, T. (1966). Societies: Evolutionary and Comparative Perspectives. New Jersey: Prentice-Hall.

Parsons, T. (1991). The Social System. London: Routledge.

Ricoeur, P. (1986). Lectures on Ideology and Utopia. New York: Columbia University Press.

Rose, G. (1981). Hegel Contra Sociology. London: Athlone Press.

Schutz, A. (1966). in The Phenomenology of the Social World, trans. G. Walsh and D. Lehnert (Evanston: Northwestern University Press).

Smith, D. (2001). Norbert Elias and Modern Social Theory. London: SAGE.

Taylor, C. (2007). A Secular Age. Cambridge, MA: Harvard University Press.

Van Krieken, R. (1998). Norbert Elias. London: Routledge.

Wagner, P. (2005). "Palomar's questions. the axial age hypothesis, European modernity and historical contingency," in Axial Civilizations and World History, eds J. P. Arnason, S. Eisenstadt, and B. Wittrock (Leiden, Boston: Brill), 87-106.

Wagner, P. (2008). Modernity as Experience and Interpretation. Cambridge: Polity Press.

Wagner, P. (2012). Modernity: Understanding the Present. Cambridge: Polity Press.

Wagner, P. (2015). Interpreting the present: a research programme. Soc. Imaginaries 1, 105-129. doi:10.5840/si2015117

Wagner, P. (2016). Progress: A Reconstruction, Kindle Edn. Cambridge: Polity.

Wallerstein, I. (1987). "World-systems analysis," in Social Theory Today, eds A. Giddens and J. Turner (Stanford, CA: Stanford University Press), 309-324.

Wallerstein, I. (1991). "Marx and history: fruitful and unfruitful emphases," in Race, Nation, Class: Ambiguous Identities, eds É. Balibar and I. Wallerstein (London, New York: Verso), 125-134.

Weber, M. (1992). in The Protestant Ethic and the Spirit of Capitalism, ed. T. Parsons (London, New York: Routledge).

Wernick, A. (2001). August Comte and the Religion of Humanity: The PostTheistic Program of French Social Theory. Cambridge: Cambridge University Press.

Wittrock, B. (2005). “The meaning of the axial age," in Axial Civilizations and World History, eds J. P. Arnason, S. Eisenstadt, and B. Wittrock (Leiden, Boston: Brill), $51-86$.

Conflict of Interest Statement: The author declares that the research was conducted in the absence of any commercial or financial relationships that could be construed as a potential conflict of interest.

Copyright $\odot 2017$ Mouzakitis. This is an open-access article distributed under the terms of the Creative Commons Attribution License (CC BY). The use, distribution or reproduction in other forums is permitted, provided the original author(s) or licensor are credited and that the original publication in this journal is cited, in accordance with accepted academic practice. No use, distribution or reproduction is permitted which does not comply with these terms. 